https://helda.helsinki.fi

Alcohol intake in two different mouse drinking models after recovery from the lipopolysaccharide-induced sickness reaction

\title{
Lainiola, Mira
}

$2017-12$

Lainiola , M \& Linden , A-M 2017 , ' Alcohol intake in two different mouse drinking models after recovery from the lipopolysaccharide-induced sickness reaction ' , Alcohol (New York), vol. 65 , pp. 1-10 . https://doi.org/10.1016/j.alcohol.2017.06.002

http://hdl.handle.net/10138/298149

https://doi.org/10.1016/j.alcohol.2017.06.002

publishedVersion

Downloaded from Helda, University of Helsinki institutional repository.

This is an electronic reprint of the original article.

This reprint may differ from the original in pagination and typographic detail.

Please cite the original version. 


\title{
Alcohol intake in two different mouse drinking models after recovery from the lipopolysaccharide-induced sickness reaction
}

\author{
Mira Lainiola, Anni-Maija Linden* \\ Department of Pharmacology, Faculty of Medicine, University of Helsinki, Finland
}

\section{A R T I C L E I N F O}

\section{Article history:}

Received 17 February 2017

Received in revised form

19 May 2017

Accepted 12 June 2017

\section{Keywords:}

Neuroinflammation

Lipopolysaccharide

Alcohol consumption

Individually ventilated cages

Mouse

\begin{abstract}
A B S T R A C T
Neuroinflammation may play an important role in the development of alcohol addiction. Recent preclinical reports suggest that enhanced innate immune system signaling increases consumption of alcohol. Our aim was to study whether consequences of lipopolysaccharide (LPS)-induced sickness reaction increase long-term alcohol intake. Adult male C57BL/6J mice, housed in individually ventilated cages, were injected with LPS intraperitoneally (i.p.) and allowed to recover from an acute sickness reaction for 1 week before analysis of their alcohol intake in two different drinking models. Effects of LPS challenge were tested in a continuous two-bottle free choice test with increasing concentrations of alcohol and in a drinking in the dark (DID) binge model. In addition, the effect of repeatedly administered LPS during abstinence periods between binge drinking was analyzed in the DID model. In addition, the DID model was used to study the effects of the microglia inhibitor minocycline (50 mg/ $\mathrm{kg} /$ day, 4 days $)$ and purinergic P2X7 receptor antagonist Brilliant Blue G $(75 \mathrm{mg} / \mathrm{kg} /$ day, 7 days) on alcohol intake. In contrast to previous findings, pretreatment with a $1-\mathrm{mg} / \mathrm{kg}$ dose of LPS did not significantly increase ethanol consumption in the continuous two-bottle choice test. As a novel finding, we report that increasing the LPS dose to $1.5 \mathrm{mg} / \mathrm{kg}$ reduced consumption of 18 and $21 \%(\mathrm{v} / \mathrm{v}$ ) ethanol. In the DID model, pretreatment with LPS $(0.2-1.5 \mathrm{mg} / \mathrm{kg})$ did not significantly alter $15 \%$ or $20 \%$ ethanol consumption. Neither did repeated LPS injections affect binge alcohol drinking. Minocycline reduced alcohol, but also water, intake regardless of LPS pretreatment. No data on effects of P2X7 antagonists on alcohol consumption have been previously published; therefore, we report here that subchronic Brilliant Blue $\mathrm{G}$ had no effect on alcohol intake in the DID model. As a conclusion, further studies are needed to validate this LPS model of the interaction between immune system activation and alcohol consumption.
\end{abstract}

() 2017 Elsevier Inc. All rights reserved.

\section{Introduction}

Increased expression of innate immune signaling molecules may play an important role in the development of alcohol addiction as well as in the neuropathological problems caused by chronic alcohol use (Crews, Zou, \& Qin, 2011; Hutchinson \& Watkins, 2014). Increasing evidence, gathered from both rodent models and post mortem human studies, indicates that chronic high-dose alcohol exposure increases, through high-mobility group box 1 (HMGB1) and Toll-like receptor 4 (TLR4) signaling and nuclear factor-kappa B $(\mathrm{NF}-\kappa \mathrm{B})$ activation, brain expression of proinflammatory cytokines,

\footnotetext{
* Corresponding author. Department of Pharmacology, Faculty of Medicine, University of Helsinki, POB 63 (Haartmaninkatu 8), 00014 University of Helsinki, Finland.

E-mail address: anni-maija.linden@helsinki.fi (A.-M. Linden).
}

including tumor necrosis factor- $\alpha$ (TNF $\alpha$ ), interleukin (IL)-1 $\beta$, IL-6, and chemokine monocyte chemotactic protein-1 (MCP-1), as well as oxidases and proteases (reviewed in Crews et al., 2015). However, less is known about what role this neuroinflammation plays in regulation of alcohol consumption, reward, and alcohol addiction.

Several immune system molecules are linked to regulation of alcohol drinking in rodent models (Harris \& Blednov, 2013). For example, genetic deletions of various immune signaling molecules reduced alcohol consumption in knockout mice (Blednov et al., 2012). Mice overexpressing IL-6 showed increased alcohol preference (Harris \& Blednov, 2013), and an infusion of an IL-1 receptor antagonist into the mouse basolateral amygdala reduced alcohol intake (Marshall et al., 2016). Moreover, decreasing abnormally high expression of TLR4 or MCP-1 in the central amygdala or ventral tegmental area reduced alcohol self-administration in alcohol-preferring P rats (June et al., 2015). The role of immune signaling in regulation of alcohol consumption in humans is 
suggested by genetic studies showing that polymorphisms of NF- $\kappa B$ subunits, IL1 $\beta$ and IL10 are associated with susceptibility to alcoholism (Edenberg et al., 2008; Marcos, Pastor, González-Sarmiento, \& Laso, 2008; Pastor, Laso, Romero, \& González-Sarmiento, 2005). Additionally, variants of a purinergic P2X7 receptor gene have been linked to alcoholism with co-morbid mood and anxiety disorders (Mantere et al., 2012; Soronen et al., 2011). Moreover, Leclercq and others found that in non-cirrhotic alcoholics, increased intestinal permeability and blood cytokine levels correlated with alcohol craving scores (Leclercq et al., 2012, 2014). Enhanced gut permeability also led to the increased levels of blood lipopolysaccharide (LPS) in alcohol-dependent subjects.

Systemic administration of LPS, an endotoxin from gramnegative bacteria, elicits an innate immune response in the periphery and central nervous system, which has been widely used to study the role of immune signaling in depression, and has been used at high doses to model consequences of sepsis in animals (Dantzer, O'Connor, Freund, Johnson, \& Kelley, 2008; Hoogland, Houbolt, van Westerloo, van Gool, \& van de Beek, 2015). An acute sickness reaction induced by LPS is characterized by endocrine, autonomic, and behavioral changes including reduced locomotor activity, reduced food and water intake, social withdrawal, and anhedonia. Although these typical behavioral symptoms last one or two days, neuroinflammation and its consequences on neuronal functions appear to persist in the brain longer. For example, moderate doses of LPS $(0.3-3 \mathrm{mg} / \mathrm{kg}$, i.p.) produced increases in TNF $\alpha$, MCP-1, and IL-1 $\beta$ levels in the mouse brain, which lasted at least 1 week (Qin et al., 2008). Moreover, Blednov and others (2011) have shown that pretreatment with LPS ( $1 \mathrm{mg} / \mathrm{kg}$, i.p.) enhanced alcohol consumption 1 week later in mice.

Our aim here was to utilize the model of enhanced alcohol intake by pretreatment with LPS described earlier (Blednov et al., 2011), in search for an in vivo test for studies of interactions between inflammation and alcohol consumption. Because we did not observe the expected enhancement of alcohol drinking in the continuous two-bottle choice model, we next tested the putative effects of LPS challenge in the drinking in the dark (DID) binge model. Finally, although alcohol consumption was not enhanced after LPS treatments, the capacity of two drugs known to modulate neuroinflammation (the microglia inhibitor minocycline and the purinergic P2X7 receptor antagonist Brilliant Blue G) was also tested in the DID model.

\section{Materials and methods}

\section{Animals}

Male C57Black/6J $\left(\mathrm{Jax}^{(\mathbb{R}}\right.$ ) mice were purchased via Scanbur (a distributor of Charles River, Germany) and transferred at least 2 weeks before experimentation to the animal facility (specific pathogen-free) of the University of Helsinki. Mice were housed in individually ventilated cages (Greenline, Tecniplast, Italy; polysulfone cage, polysulfone/stainless-steel grid top) lined with aspen chip bedding under 12:12-h light:dark cycles (lights on from 6:00 a.m. to 6:00 p.m., unless otherwise noted), at $21-23{ }^{\circ} \mathrm{C}$ and a relative humidity of $45 \pm 10 \%$, and received standard rodent pellets (Harlan Teklad 2918, Envigo, Madison, WI, USA) and tap water ad libitum (unless otherwise noted). The cages were equipped with a wood block (aspen, $1 \times 1 \times 5 \mathrm{~cm})$ and four sheets $(6 \times 6 \mathrm{~cm})$ of thin tissue paper (cellulose wadding) as enrichment, which were changed once every 2 weeks at the same time as cages were changed, and scheduled on days when alcohol drinking was not analyzed. The numbers of animals used in the treatment groups are shown in the figures. All efforts were made to minimize animal suffering and reduce the number of animals used. All animal procedures were approved by the Southern Finland Provincial Government.

\section{Drugs}

LPS (E. coli strain 0111:B4, L4391) was obtained from Sigma (St. Louis, MO, USA). Minocycline hydrochloride and Brilliant Blue G were obtained from Abcam (Cambridge, UK). All drugs were freshly dissolved in pyrogen-free, sterile saline. The $\mathrm{pH}$ of minocycline hydrochloride solution was adjusted close to 7 with sodium hydroxide. All other drugs were administered (i.p.) at a volume of $10 \mathrm{~mL} / \mathrm{kg}$, except minocycline, which was injected (i.p.) at a volume of $20 \mathrm{~mL} / \mathrm{kg}$. For alcohol drinking, ethanol (96\% v/v, GPR Rectapur, VWR Chemicals, France) was diluted with tap water into $3-21 \%$ (v/v) concentrations.

\section{LPS treatment and recovery}

Mice were housed in single cages before LPS pretreatments, which were given at the age of 12 weeks, except in the second continuous two-bottle choice test, when the mice were 7 weeks old, and during repeated LPS injections when the mice were 18-22 weeks old. LPS doses (i.p.) were in the continuous two-bottle choice model at $1-1.5 \mathrm{mg} / \mathrm{kg}$ and in the DID models at $0.2-1.5 \mathrm{mg} / \mathrm{kg}$. Body weights and water consumption were monitored daily a few days before LPS and during the recovery period; otherwise, the mice were let undisturbed. Alcohol drinking was started 7 days after LPS injections in other experiments, except when testing the effects of repeated LPS injections, when alcohol drinking was started 4 days after LPS.

\section{LPS pretreatment in the continuous two-bottle choice drinking model}

The continuous 24-h two-bottle choice drinking model was performed essentially as described earlier (Blednov et al., 2011). Mice were single-housed in larger individually ventilated cages $(30 \times 30 \times 17 \mathrm{~cm})$ with two holes on the top for placement of drinking bottles or tubes. A water bottle was replaced by a water tube 3 days before LPS treatment. Tubes were used thereafter. Both water and ethanol were delivered from graduated $20-\mathrm{mL}$ tubes affixed to double-ball bearing metal sippers. The position of ethanol and water tubes were changed daily after reading the volume at approximately $4 \mathrm{~h}$ after lights were turned on. Tap water was always available.

A single LPS injection (1-1.5 $\mathrm{mg} / \mathrm{kg}$ ) was given in the morning (between 9:00 and 11:00 a.m.). Alcohol drinking was started 1 week after LPS treatment, first at 3\% concentration that was available for 2 days, after which increasing concentrations (6\%, 9\%, $12 \%$, $15 \%, 18 \%$, and $21 \%$ ) were offered each for 48 h during a 14-day period. Mice were weighed every other day. After a 1-week alcohol deprivation period, the same drinking procedure was repeated twice. The volume measurement was done by reading from the graduated scale on the drinking tube to the nearest $0.2 \mathrm{~mL}$. Estimates of spillage and evaporation obtained from water and ethanol control tubes, placed in the empty cages, were subtracted from daily ethanol and water intakes. A final daily intake $(\mathrm{g} / \mathrm{kg} /$ $24 \mathrm{~h}$ ) was a mean of 2 days.

\section{LPS pretreatment in the binge-drinking model (DID 15\% ethanol)}

The limited-access binge drinking model was adapted from a DID procedure described earlier (Rhodes, Best, Belknap, Finn, \& Crabbe, 2005). Mice were single-housed in small individually ventilated cages $(16 \times 30 \times 12 \mathrm{~cm}$, with one hole on the top for a 
drinking bottle/tube) and habituated to a reversed light cycle (lights off from 7:00 a.m. to 7:00 p.m.) 2 weeks before LPS treatment. A single LPS injection $(0.2-1.5 \mathrm{mg} / \mathrm{kg}$, details of dosing in different batches, see below) was given between 9:00 and 11:00 a.m. Body weight and water consumption were measured daily during a 1-week recovery period. Water consumption was measured by weighing water bottles to the nearest $0.1 \mathrm{~g}$, because drinking tubes were used only for DID measurements. After recovery, the DID procedure was begun, and a water bottle was replaced by a $10-\mathrm{mL}$ tube affixed to a double ball-bearing metal sipper and containing 15\% ethanol, $3 \mathrm{~h}$ after lights were turned off (dim red light was always on). For the first drinking week, the mice had access to alcohol for $2 \mathrm{~h}$ during the first 3 days and access for $4 \mathrm{~h}$ on the fourth day, followed by a 3-day break. The next week was similar, but on the third week and always thereafter mice had access to alcohol for $4 \mathrm{~h}$ on each drinking day. This 7-day DID procedure was continued for several weeks (see Fig. 1 for a study design). The volume of consumed ethanol was recorded at 2-h and 4-h time points by reading from the graduated scale on the drinking tube to the nearest $0.1 \mathrm{~mL}$. The amount of consumed water during the rest of the day (approximately $19 \mathrm{~h}$ ) was recorded by weighing the water bottles. Liquid measurements were corrected for leakage and evaporation based on control tubes/bottles in the empty cages.

Drug effects on alcohol intake in the binge drinking model (DID 15\% ethanol)

The effects of minocycline and Brilliant Blue $\mathrm{G}$ on alcohol consumption were analyzed in the mice which were pretreated with saline or LPS, and then had access to alcohol during several DID weeks, as indicated in Fig. 1. Before minocycline treatment the mice had had access to 15\% alcohol for three DID weeks (Fig. 1A). Minocycline ( $50 \mathrm{mg} / \mathrm{kg}$, i.p.) or vehicle was administered repeatedly for 4 days, always $20 \mathrm{~h}$ before access to alcohol. Dosing was based on earlier reports (Agrawal, Hewetson, George, Syapin, \& Bergeson, 2011; Agrawal et al., 2014). In a separate batch of mice also having had access to $15 \%$ ethanol for three DID weeks, the effect of the same minocycline treatment procedure was analyzed on 4-h water consumption (Fig. 1B).

Brilliant Blue $\mathrm{G}$ ( $75 \mathrm{mg} / \mathrm{kg}$, i.p.) was administered daily for 7 days, 3 days before the next DID period and 4 days during DID testing when injections were $1 \mathrm{~h}$ before access to alcohol (Fig. 1C). Dosing was based on previous behavioral effects of Brilliant Blue $\mathrm{G}$ in mice (Csölle et al., 2013).

A $15 \% \mathrm{EtOH}$ (results in Fig. 4A-C)

Mino

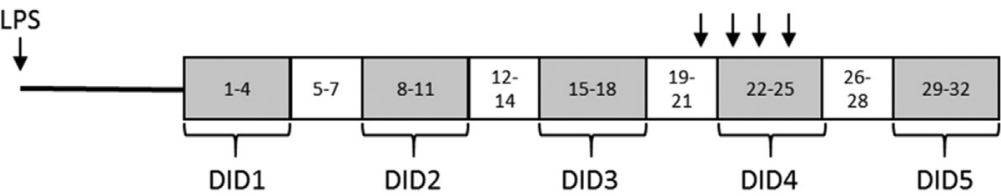

B $15 \% \mathrm{EtOH} /$ water during DID4 (results in Fig. 4D-F)

Mino

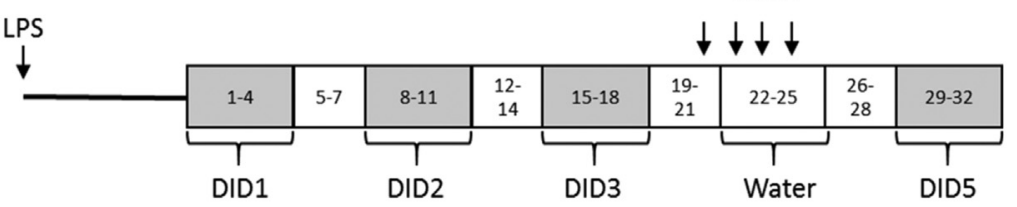

C $15 \%$ EtOH (results in Fig. 5)

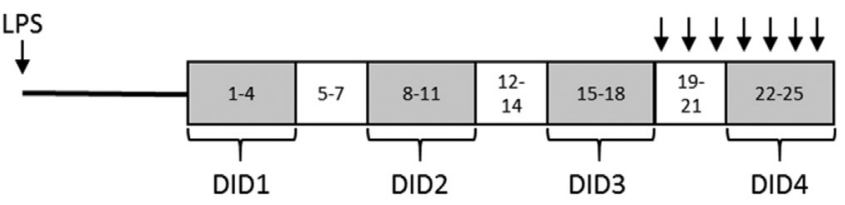

D $20 \%$ EtOH and repeated LPS (results in Fig. 6)

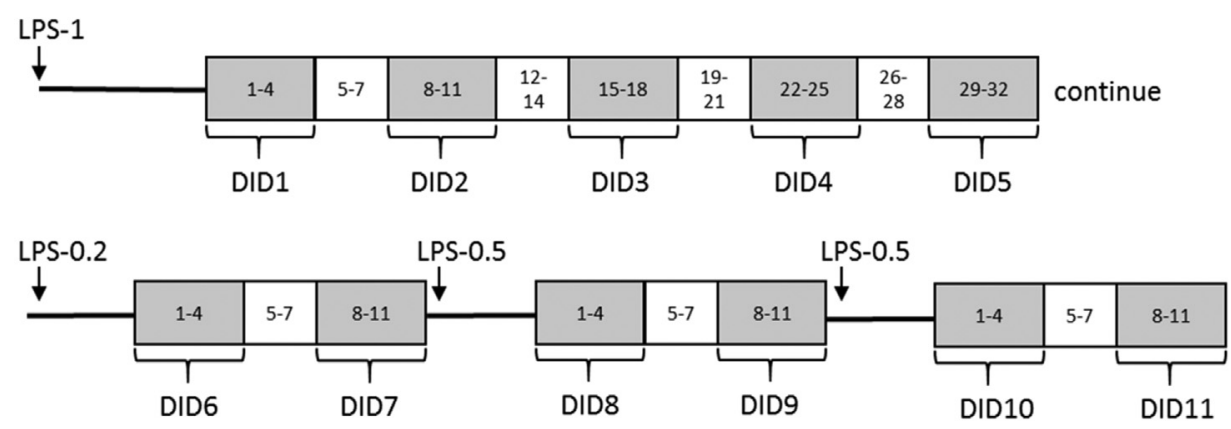

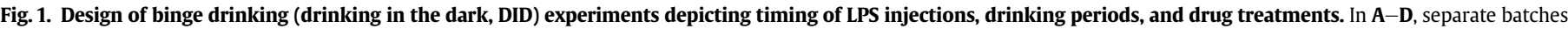

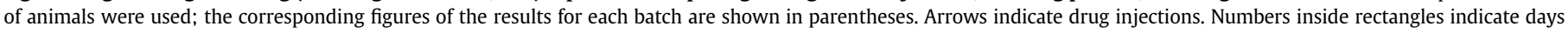
during DID and abstinence periods. BBG, Brilliant Blue G; EtOH, ethanol; LPS, lipopolysaccharide; Mino, minocycline. 
Repeated dosing of LPS in the binge drinking model (DID 20\% ethanol)

To study the effect of LPS on mice which were already exposed to LPS and alcohol, the mice were first pretreated with saline or LPS ( $1 \mathrm{mg} / \mathrm{kg}$, at the age of 12 weeks), allowed to consume $20 \%$ ethanol during five DID periods (DID procedure as described above), then a low dose of LPS $(0.2 \mathrm{mg} / \mathrm{kg}$, at the age of 18 weeks) was administered $24 \mathrm{~h}$ after the last drinking period, and the DID procedure was started again after a 4-day recovery period when the body weight and water consumption were normalized. After 2 weeks, this procedure was repeated two times with a higher dose of LPS (0.5 mg/kg) (Fig. 1D).

\section{Statistical testing}

Statistical analyses of the data were carried out using one-way ANOVA, two-way ANOVA, and two-way repeated-measures ANOVA (RM ANOVA), followed by Bonferroni post hoc test or Student's $t$-test with the statistical software packages IBM SPSS (version 21, IBM Corp., Armonk, NY, USA) and PRISM 5.0 (GraphPad Software Inc., La Jolla, CA, USA). Statistical significance was set at $p<0.05$. Data are expressed as mean \pm standard error of the mean (SEM).

\section{Results}

Alcohol intake in the continuous two-bottle choice drinking model after LPS pretreatment

As expected, systemic LPS produced a sickness reaction that lasted several days. In the 12-week-old mice, both doses of LPS (1 and $1.5 \mathrm{mg} / \mathrm{kg}$ ) caused a significant weight loss of approximately $12 \%$ and an almost complete cessation in water intake 1 day after injections (Fig. 2A and B). The mice treated with either dose regained their body weights, and the percent of pre-LPS body weights reached the level of the controls 6 days after LPS (Fig. 2A; treatment, $F_{(2,182)}=39.5, p<0.001$; day $\times$ treatment interaction, $F_{(14,182)}=36.6, p<0.001$, two-way RM ANOVA). However, absolute body weights (in grams) of the mice treated with the $1.5-\mathrm{mg} / \mathrm{kg}$ dose of LPS remained significantly lower than the controls until the end of the first drinking test, probably due to slightly lower pre-LPS body weights (Supporting Table S1). Water intake was significantly lower only on the first day after LPS. On the third day, the mice treated with $1 \mathrm{mg} / \mathrm{kg}$ LPS consumed significantly more water than the saline group. Thereafter, water intake did not differ (Fig. 2B; day $\times$ treatment interaction, $F_{(14,182)}=22.4, p<0.001$ ).

After a 1-week recovery, alcohol consumption was studied in three 2-week drinking tests (Fig. 2C-F). During the first 2 weeks, the pretreatment with LPS significantly affected alcohol intake (treatment effect, $F_{(2,26)}=7.8, p<0.01$; concentration $\times$ treatment interaction, $\left.F_{(12,156)}=2.0, p<0.05\right)$. The higher $1.5-\mathrm{mg} / \mathrm{kg}$ dose significantly reduced alcohol intake compared to the mice treated with saline or $1-\mathrm{mg} / \mathrm{kg}$ dose (Fig. 2C). Pretreatment with $1-\mathrm{mg} / \mathrm{kg}$ LPS did not alter alcohol consumption at any concentration compared with the saline group. The mice treated with $1.5-\mathrm{mg} / \mathrm{kg}$ LPS preferred alcohol less than the other two groups (treatment effect, $\left.F_{(2,26)}=4.1, p<0.05\right)$. This was evident at the concentrations of $9 \%$ and $12 \%$ when compared with the $1-\mathrm{mg} / \mathrm{kg}$ LPS-treated mice (Fig. 2D). After a 1-week deprivation period, the pretreatment with LPS did not significantly affect consumption of alcohol, which was lower overall than in the first drinking test (Fig. 2E). The alcohol drinking levels did not differ between treatment groups in the third test, which was performed again after a 1-week deprivation (Fig. 2F).
Additionally, younger, 7-week-old mice were treated with LPS ( $1 \mathrm{mg} / \mathrm{kg}$ ) to test whether they would show the hypothesized enhancing effect on alcohol drinking. The mice recovered from the acute LPS reaction essentially similarly (Supporting Table S2) to the 12-week-old mice. LPS did not alter significantly alcohol intake, although there was a slight, but non-significant, reduction at the highest ethanol concentrations (Fig. 3A). Alcohol preference was affected by LPS pretreatment, depending on the concentration (concentration $\times$ treatment interaction, $F_{(6,96)}=2.5, p<0.05$; no treatment effect, two-way RM ANOVA). However, post hoc tests did not indicate any specific difference between treatment groups (Fig. 3B). The pretreatment with LPS did not significantly affect consumption of alcohol in the second or third test both performed after 1 week of deprivation (data not shown).

Alcohol intake in the binge-drinking model (DID 15\% ethanol) after LPS pretreatment and minocycline treatment

The effect of LPS pretreatment was also analyzed in a binge alcohol-drinking model, first using 15\% (v/v) ethanol. As before, LPS produced a sickness reaction that lasted several days. The percent of pre-LPS body weights were significantly lower for 3-6 days in the LPS groups compared to the saline group (Supporting Table S3). After the first DID period (11 days after LPS), the body weight values did not differ between treatment groups. Water intake was significantly lower on the first day after all doses of LPS and $48 \mathrm{~h}$ after the highest LPS dose. Thereafter, water intake did not differ from the saline-treated mice (Supporting Table S3). After 1 week of recovery, consumption of alcohol was analyzed in the DID model, first for 3 weeks without any drug treatments (Fig. 1A). LPS pretreatment did not affect 15\% alcohol intake during this period (DID1-DID3, twoway RM ANOVA) (Fig. 4A).

To analyze the sensitivity of LPS-treated mice to the effects of minocycline, the mice from different pretreatment groups were balanced by alcohol intake and body weights to vehicle and minocycline treatment groups. Minocycline ( $50 \mathrm{mg} / \mathrm{kg}$ ) injections were given for 4 days, always $20 \mathrm{~h}$ before access to alcohol (see Fig. $1 \mathrm{~A}$ for a study design). Minocycline treatment significantly reduced alcohol intake, regardless of LPS pretreatment (Fig. 4B; minocycline treatment, $F_{(1,24)}=8.3, p<0.01$; no LPS pretreatment effect or interaction, two-way ANOVA). However, we found that daily (19 h) water intake during minocycline treatment days was also reduced (Fig. 4C; minocycline treatment, $F_{(1,24)}=5.6, p<0.05$; no LPS pretreatment effect or interaction). In addition, minocycline treatment slightly prevented the body weight gain calculated as the percent of pre-minocycline weight during DID4 regardless of LPS pretreatment (Supporting Table S3; $F_{(1,24)}=4.5, p<0.05$ ), and this difference was significant also in the end of DID5 $\left(F_{(1,24)}=11.3\right.$, $p<0.01)$. No significant reduction of alcohol intake by the previous minocycline treatment was observed during DID5, which was started 4 days after the last minocycline injection (data not shown). Additionally, daily water intake did not differ during DID5 (data not shown).

Because minocycline reduced daily (19 h) water intake, we analyzed whether minocycline would also reduce water intake at those time points when it reduced alcohol consumption, to clarify whether its actions on binge alcohol drinking could be separated from nonspecific effects on daily water intake. A separate batch of mice were pretreated with saline or $1 \mathrm{mg} / \mathrm{kg}$ LPS (Supporting Table S3) and exposed to a 3-week DID procedure with 15\% ethanol before minocycline treatment (see Fig. 1B for a study design). Pretreatment with LPS did not significantly affect alcohol intake during these DID1-3 (two-way RM ANOVA; Fig. 4D). The 4-day minocycline ( $50 \mathrm{mg} / \mathrm{kg} /$ day), administered always $20 \mathrm{~h}$ before 4 -h analysis of water consumption during the fourth DID week, did not 

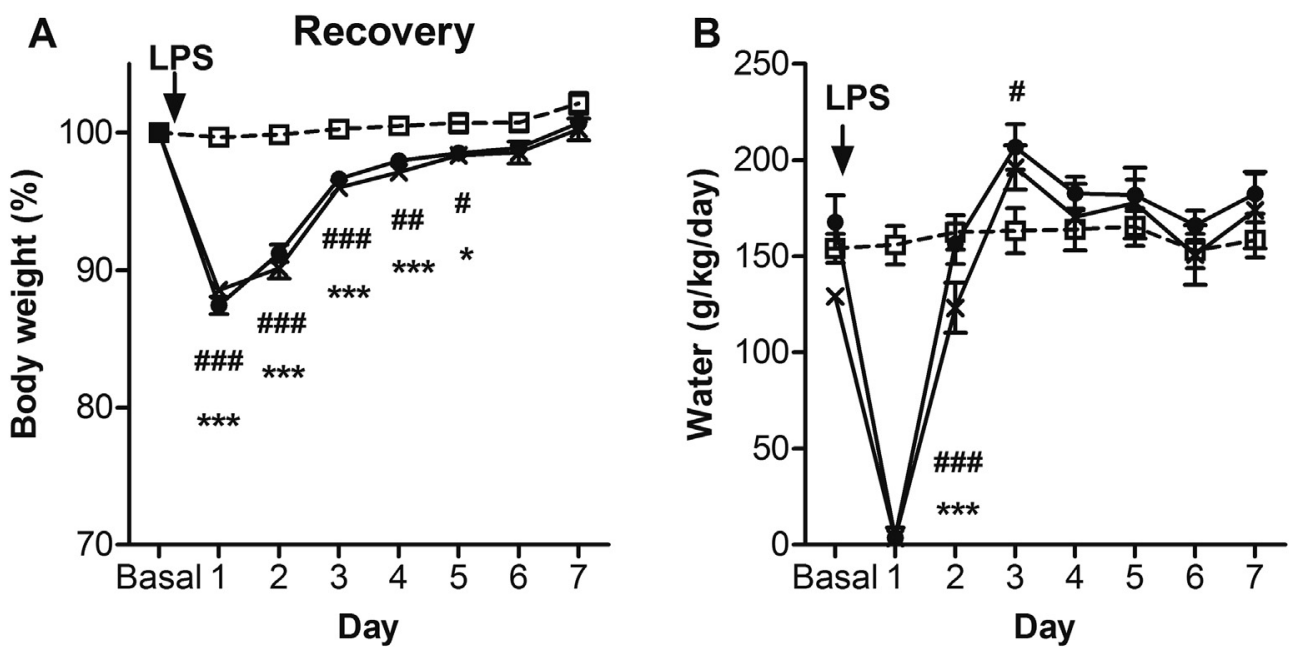

C

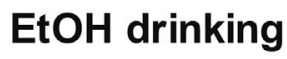

D
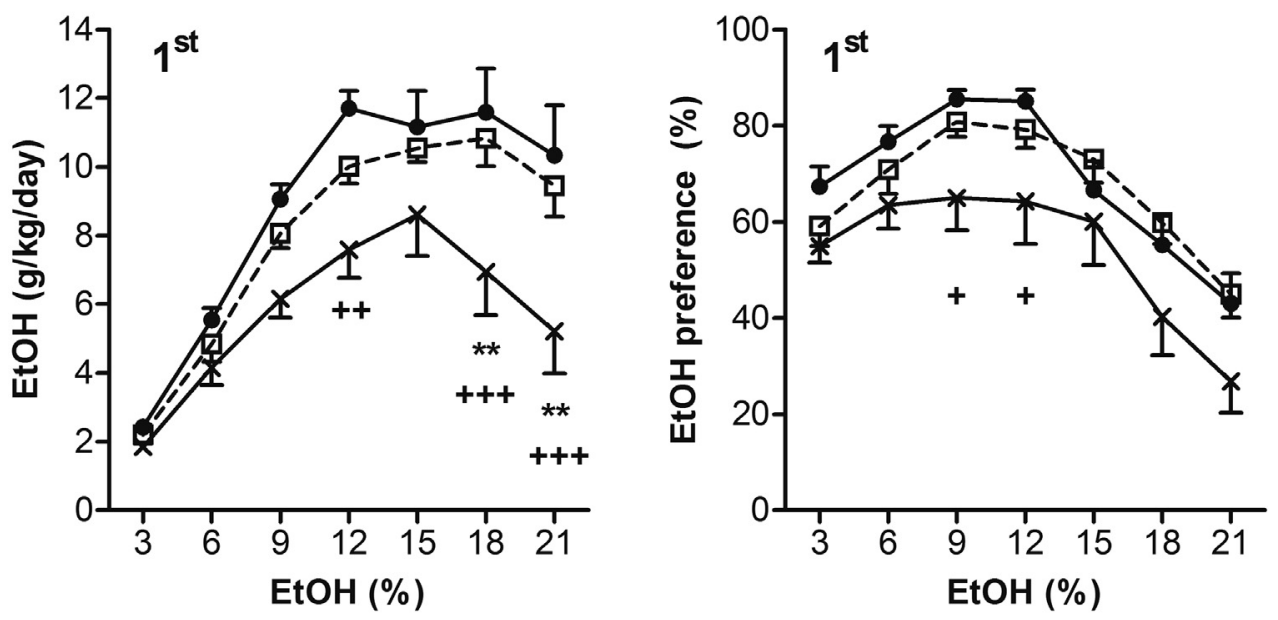

E

F
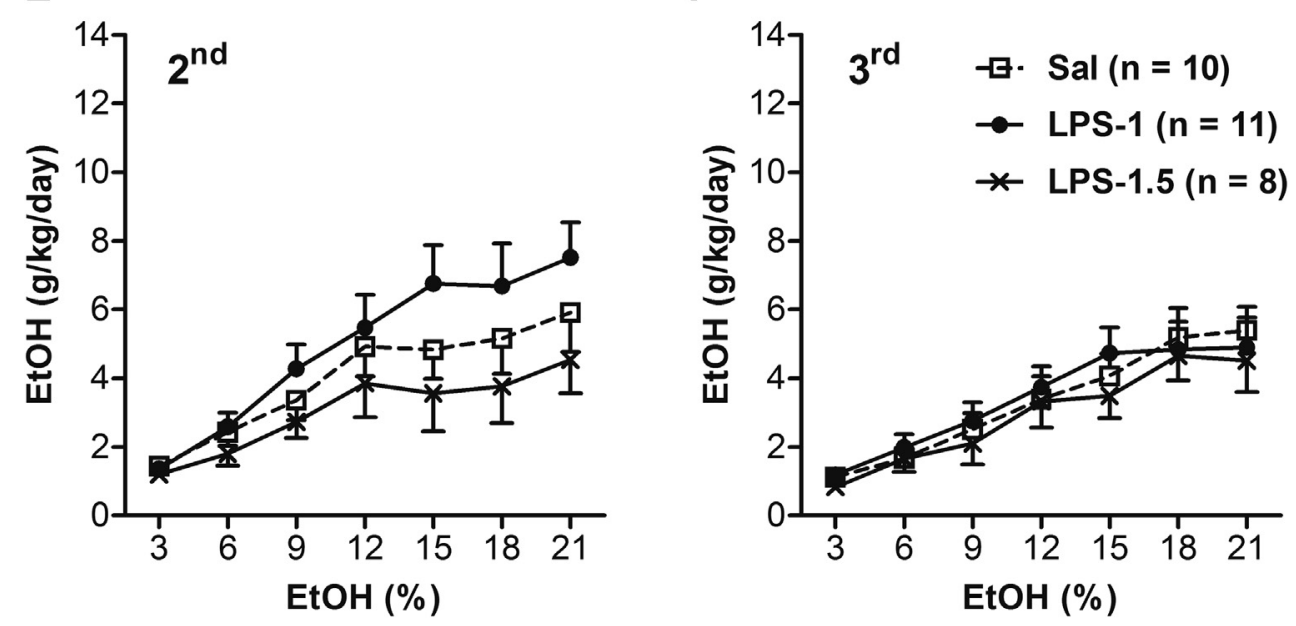

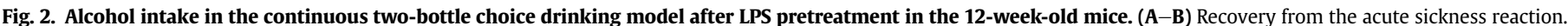

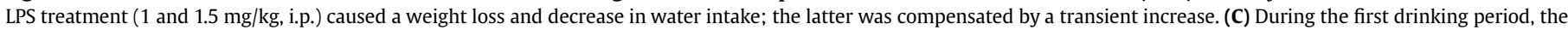

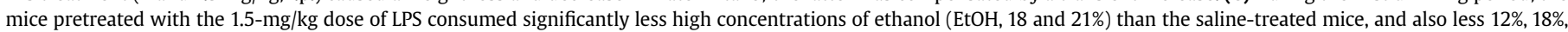

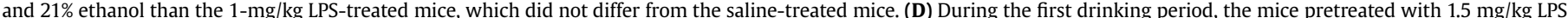

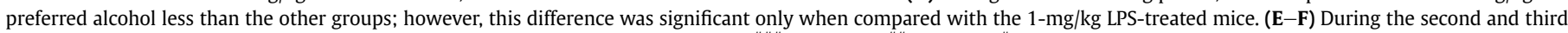

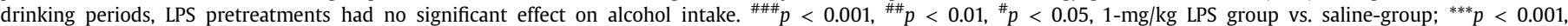

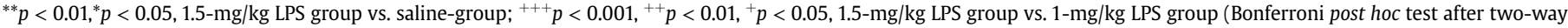
RM ANOVA). Sal, saline. 

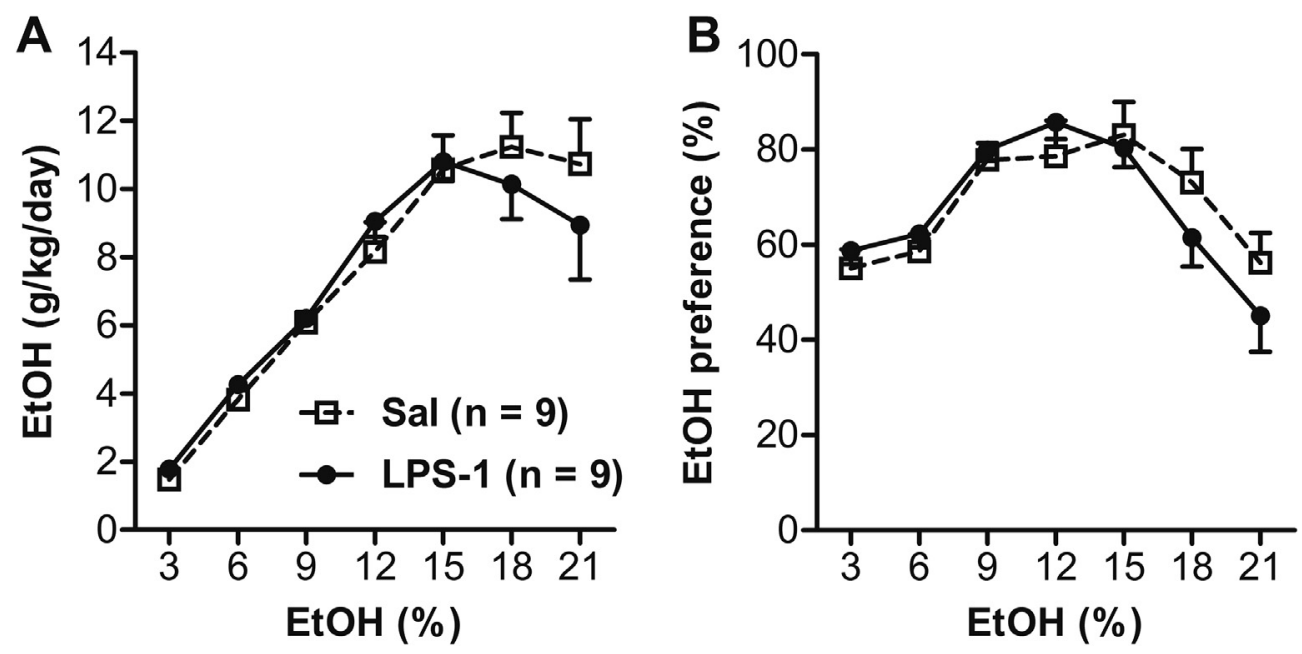

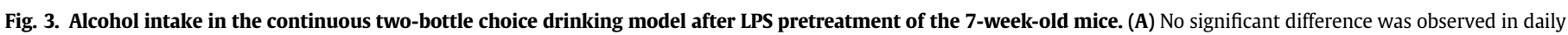

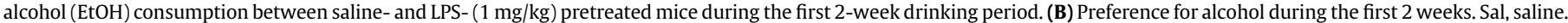

significantly affect water intake (Fig. 4E, no minocycline or LPS effect in two-way ANOVA). However, a significant reduction in 19-h water intake was observed (minocycline treatment, $F_{(1,16)}=5.9$, $p<0.05$, Fig. 4F) as in our earlier experiment (Fig. 4C). Body weight changes during minocycline treatment did not differ between the saline and minocycline treatment groups in this cohort of mice (Supporting Table S3). No significant reduction of alcohol intake by previous minocycline was observed 4 days after the last minocycline injection during DID5, neither did daily water intake differ during DID5 (data not shown).

\section{Alcohol intake in the binge drinking model (DID 15\% ethanol) after} Brilliant Blue G treatment

The effect of Brilliant Blue G (75 mg/kg/day for 7 days) on alcohol intake was analyzed during the fourth week of DID (Fig. 1C) in a separate cohort of mice, which were pretreated with either saline or LPS $(0.2,0.5$, and $1 \mathrm{mg} / \mathrm{kg})$. These mice showed similar sickness reactions as in the previous experiments (Supporting Table S4), and again displayed no effect of LPS on alcohol intake in 3-week DID (data not shown). Immediately after DID3, the mice were balanced by alcohol intake to vehicle and Brilliant Blue $G$ treatment groups, and the 7-day treatment was begun. Intake measurements during DID4 indicated that neither Brilliant Blue G treatment nor the pretreatment with LPS affected 2-h (data not shown) or 4-h ethanol intake (Fig. 5; two-way ANOVA). The body weights were not affected by Brilliant Blue G (Supporting Table S4).

\section{Alcohol intake in the binge drinking model (DID 20\% ethanol) after LPS treatments}

As the pretreatments with LPS had no effect on $15 \%$ ethanol intake, we next analyzed whether LPS treatment might alter drinking of a higher $20 \%$ ethanol concentration, and whether repeated LPS challenges between drinking periods had any effect (see Fig. 1D for a study design). The mice were pretreated with either saline or LPS, allowed to recover from the acute sickness reaction (Supporting Tables S5 and S6) and then tested first in the DID procedure for 5 weeks, after which LPS injections between drinking periods were given. LPS pretreatment $(1 \mathrm{mg} / \mathrm{kg})$ did not significantly alter 2 -h or 4 -h $20 \%$ ethanol consumption during DID1-5 (two-way RM ANOVA, Fig. 6A). Since the LPS-treated mice appeared to drink slightly more than the saline-treated mice during
DID3 and DID4 (Fig. 6A, days 15-25), these values were tested separately. However, this observation was not statistically significant.

Next, half of the saline- and LPS-pretreated mice were repeatedly treated with low doses of LPS (first $0.2 \mathrm{mg} / \mathrm{kg}$, then twice with $0.5 \mathrm{mg} / \mathrm{kg}$ ). After each LPS injection, the mice were allowed to recover for 4 days before the next DID testing, at which point their water drinking and body weights in grams did not differ from the saline-saline group (Supporting Tables S5 and S6). After the first and second repeated LPS injections, the percent of pre-LPS body weight values still slightly differed from that of the saline-saline group during the next DID period (Supporting Table S5).

Although there appeared to be a trend of an increased alcohol intake after the first $0.5-\mathrm{mg} / \mathrm{kg}$ dose during DID8 and DID9, and especially after the second $0.5-\mathrm{mg} / \mathrm{kg}$ dose during DID10, the 4-day mean of 4-h alcohol intake did not differ significantly between the treatment groups during these drinking periods (Fig. 6B; no pretreatment effect, no repeated treatment effect, no interaction, twoway ANOVA). Neither did the 2-h alcohol intake differ between treatment groups during the same drinking periods (data not shown).

\section{Discussion}

In the search for a method to study the consequences of neuroinflammation in regulation of alcohol consumption, we tested the model of increased alcohol intake after an LPS-induced sickness reaction (Blednov et al., 2011). However, we did not see significant increases in the alcohol intake or preference after LPS $(1 \mathrm{mg} / \mathrm{kg})$ pretreatment in the continuous two-bottle choice drinking test although a slight tendency toward that direction was observed. In contrast, the higher dose of LPS $(1.5 \mathrm{mg} / \mathrm{kg})$ significantly reduced alcohol intake at $18 \%$ and $21 \%$ concentrations. In the DID binge drinking model, pretreatment with LPS $(0.2-1.5 \mathrm{mg} / \mathrm{kg})$ or repeated LPS injections between DID periods did not affect alcohol (15\% or $20 \%$ ) intake. Minocycline reduced alcohol intake, but water consumption also was reduced. Finally, neither did the pretreatment with LPS alter the effect of minocycline or sensitize the mice to Brilliant Blue $\mathrm{G}$, which had no effect on binge alcohol intake.

To our knowledge, there are no earlier reports on alcohol drinking behavior of mice housed in individually ventilated cages. The alcohol intakes in our DID studies were at approximately $2 \mathrm{~g} / \mathrm{kg}$ in $2 \mathrm{~h}$ and $3.5 \mathrm{~g} / \mathrm{kg}$ in $4 \mathrm{~h}$ (15\% and 20\% ethanol), which are lower 
A

DID1-3: $15 \%$ EtOH (2 $\mathrm{h}$ or $4 \mathrm{~h}$ )

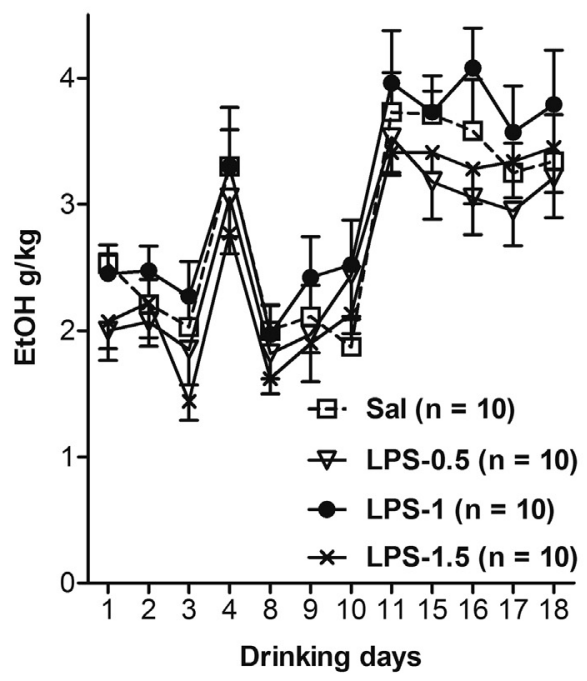

D DID1-3: $15 \%$ EtOH (2 h or $4 \mathrm{~h}$ )

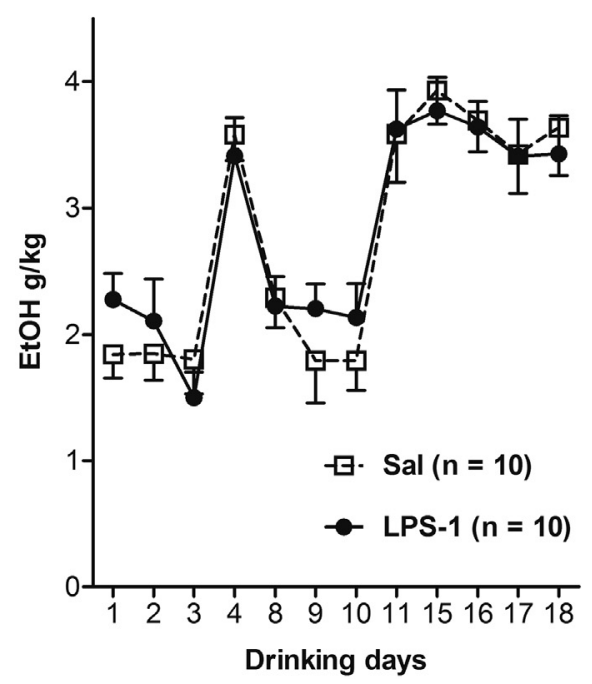

B

DID4: $15 \%$ EtOH 4-day mean (4 h)
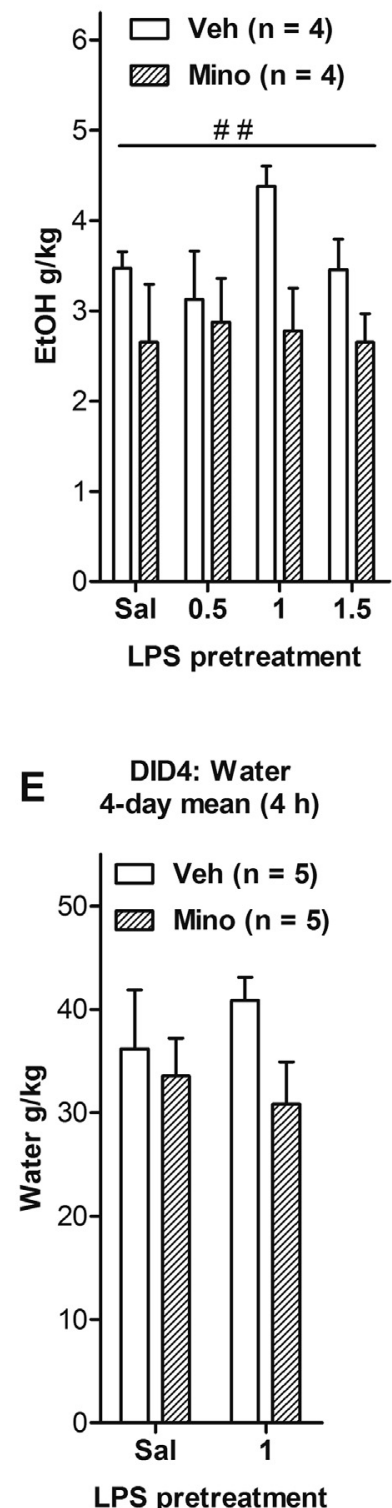
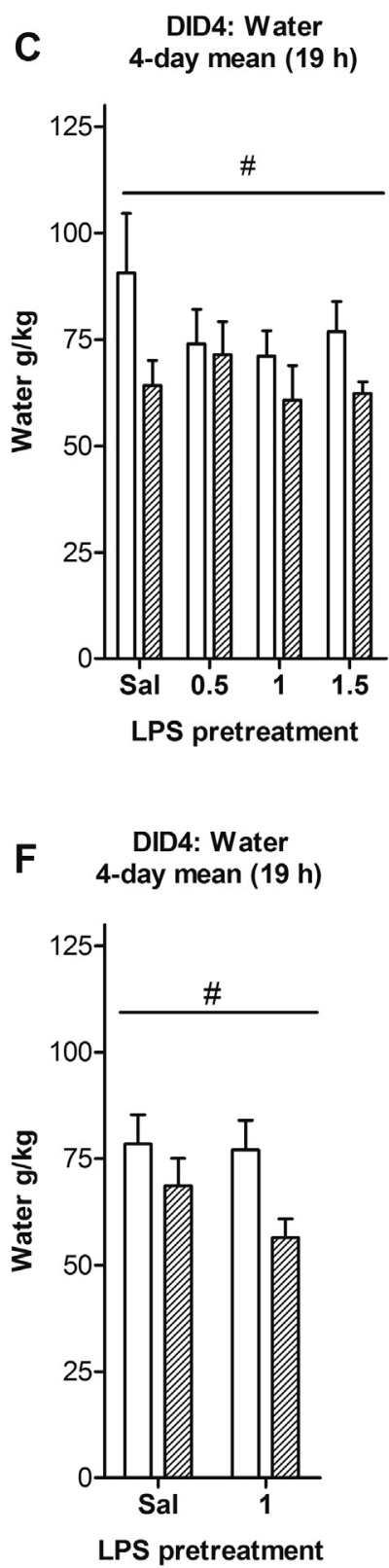

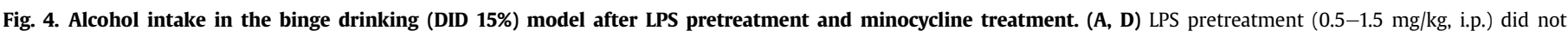

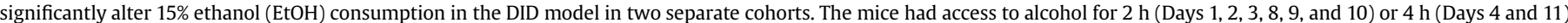

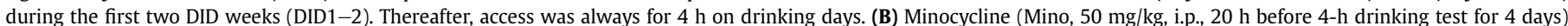

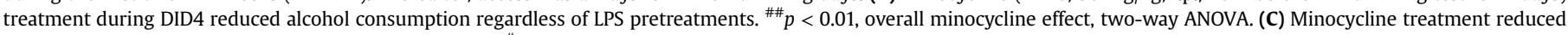

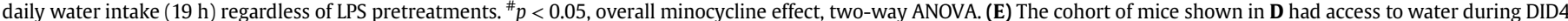

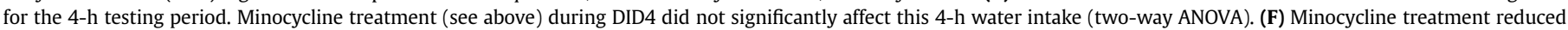
daily water intake $(19 \mathrm{~h})$ regardless of LPS pretreatments. ${ }^{*} p<0.05$, overall minocycline effect, two-way ANOVA. Sal, saline; Veh, vehicle.

than what has been reported for C57BL/6 males, which are often 4.5-6 g/kg/4 h in conventional cages (e.g., Cox et al., 2013; Hwa, Kalinichev, Haddouk, Poli, \& Miczek, 2014; Marshall et al., 2016; Nuutinen et al., 2011). Due to LPS pretreatments, the first DID cycle was started when the mice were 13 weeks old, thus they were a few weeks older than mice that are usually used for the DID model. However, also naïve C57BL/6J males, which were 8 weeks old when DID started, showed only slightly higher drinking levels $(20 \%$ ethanol during the second DID cycle: 2 -h intake $2.4 \pm 0.14 \mathrm{~g} / \mathrm{kg} ; 4-\mathrm{h}$ intake on the fourth day: $4.2 \pm 0.25 \mathrm{~g} / \mathrm{kg}$, mean $\pm \mathrm{SEM}, n=16$, unpublished observation A-M Linden). Thus, the use of individually ventilated cages appears to produce slightly lower intake levels in the DID model, although in the continuous two-bottle choice model the levels of consumed alcohol or preference were comparable to those described for C57BL/6 mice in conventional cages (e.g., Blednov et al., 2011; Nuutinen et al., 2011). Other factors that might explain the low levels of alcohol consumption include epigenetic modifications derived from different breeding/housing conditions or the enrichment that was used in the cages throughout the experiments (see below).

Although the pretreatment with LPS $(0.2-1.5 \mathrm{mg} / \mathrm{kg})$ did not significantly increase alcohol intake in any conditions used here, our finding that the $1.5-\mathrm{mg} / \mathrm{kg}$ dose of LPS reduced alcohol intake in the continuous two-bottle choice test indicates that the doses were adequate and the highest possible. In the binge DID model, the 1.5$\mathrm{mg} / \mathrm{kg}$ dose of LPS did not reduce alcohol intake, suggesting that the 


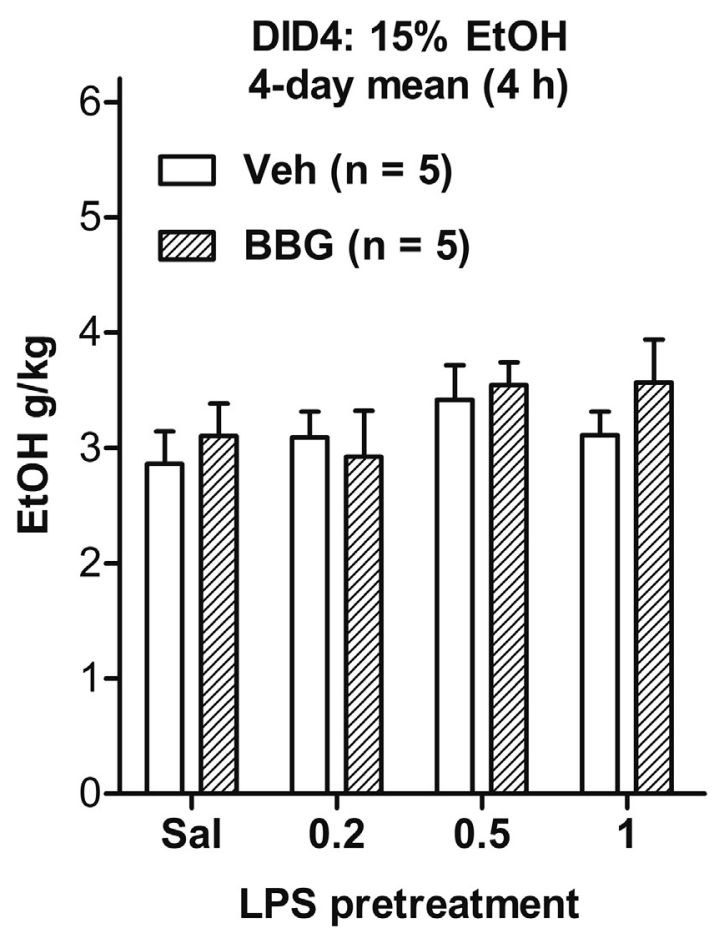

Fig. 5. Alcohol intake in the binge drinking (DID 15\%) model after subchronic treatment with Brilliant Blue G. Pretreatment with LPS $(0.2-1 \mathrm{mg} / \mathrm{kg}$, i.p.) did not affect alcohol drinking during DID1-3 (data not shown) nor during DID4. Subchronic Brilliant Blue G (BBG, $75 \mathrm{mg} / \mathrm{kg} /$ day) treatment for 7 days did not alter 4-h $15 \%$ ethanol (EtOH) consumption during DID4. Sal, saline; Veh, vehicle.

observed decrease is related to those traits the two-bottle choice test is more sensitive to measure, such as changes in taste perception or aversion of alcohol solutions in a situation when there is always also water available.

The lack of an expected LPS effect is somewhat surprising, as the acute sickness reaction after LPS administration was evident and essentially similar in our mice as described by Blednov et al. (2011), with approximately $10-12 \%$ weight loss $24 \mathrm{~h}$ after LPS, and an almost complete cessation of water intake for $24 \mathrm{~h}$ after LPS. In addition, alcohol intake and preference of control mice were at a similar level to what was reported by Blednov et al. (2011) for male C57BL/6J mice. Although these parameters were closely similar, many factors, including microbiological status of animals, rodent diet used (Marshall et al., 2015), and our use of individually ventilated cages can modulate consequences of LPS challenge, producing the lack of expected enhancing effect on alcohol intake. For example, a recent study indicates a strong impact of microbiological status of animal husbandry on the mouse immune system (Beura et al., 2016). In addition, environmental enrichment affects many reward-related behaviors and specifically, it has been shown to reduce stress-induced alcohol consumption in mice (Bahi, 2017; Marianno, Abrahao, \& Camarini, 2017). Thus, it is possible that the enrichment we used contributes to the contrasting results. Additionally, epigenetic factors derived from unidentified differences in breeding and housing conditions might contribute to the different outcome in our studies (Wolstenholme et al., 2011). Finally, as alcohol consumption in mice depends strongly on the genetic background (Crabbe, Phillips, \& Belknap, 2010), it is possible that C57BL/6J mice obtained at different times and from different providers differ in their sensitivity for modulatory actions of LPS pretreatment due to a genetic drift (although see Wahlsten, Bachmanov, Finn, \& Crabbe, 2006). However, Blednov et al. (2011) were able to demonstrate the efficacy of LPS pretreatment in increasing alcohol consumption also in the hybrid strains FVBXB6F1 and NZBxB6F1, at least in females. Thus, their observation was not dependent on the genetic background of C57BL/6J.

It was not shown which component in the LPS-induced inflammation mediates the increased alcohol intake observed by Blednov et al. (2011). Thus, we did not analyze brain cytokine or chemokine levels or microglia activation after LPS, as it is not known what alterations in the brain actually mediate the reported LPS-induced changes in alcohol intake. There could also be persistent changes in neuronal functions when the initial immune challenge has faded away. Nevertheless, an obvious weakness of our report is the unknown level of neuroinflammation produced by LPS immediately after treatment and during the analysis of alcohol drinking.

While waiting for the reports from other laboratories on utilizing the model, it appears that the influence of the LPS challenge on alcohol consumption is dependent on currently unknown conditions, rendering the model susceptible to inter-laboratory differences. Consistent with our findings, a very recent study indicated that LPS challenge did not increase alcohol self-administration 1 or 2 weeks later in rats (Harris et al., 2016).

Since pretreatment did not alter alcohol intake in the DID model, we gave repeated LPS injections between DID cycles in order to test whether LPS would promote alcohol intake during the following DID cycles, for example, due to enhanced withdrawal reactions. Alcohol intake was analyzed after the recovery period when the water consumption had normalized to the level of control animals. This treatment did not significantly affect alcohol intake, although there was a trend of an increase during DID10 in the group of mice which had received LPS before the DID procedure and also between the DID cycles. Comparison of water consumption and body weights after repeated LPS injections suggests formation of some tolerance to the sickness reaction, which is consistent with previous reports (Banasikowski, Cloutier, Ossenkopp, \& Kavaliers, 2015; Engeland, Nielsen, Kavaliers, \& Ossenkopp, 2001). Thus, it is possible that higher repeated LPS doses might have produced clearer effects on alcohol intake, but this remains to be studied.

Several different drugs modulating brain immune signaling have been shown to affect alcohol consumption (reviewed in Ray, Roche, Heinzerling, \& Shoptaw, 2014). As these effects have been seen on basal alcohol intake, we decided to test two drugs known to target immune signaling molecules, in a search for other tools to study hypothesized interaction between neuroinflammation and alcohol consumption, even though an LPS challenge did not increase alcohol intake. First, we tested the effect of minocycline, which has been shown to suppress microglia activation in the brain (Henry et al., 2008; Taylor et al., 2015), but could also have many other targets (Möller et al., 2016). Repeated treatment with minocycline reduced alcohol intake in our DID model, consistent with previous findings (Agrawal et al., 2014, 2011; Mclver, Muccigrosso, \& Haydon, 2012). No difference in response to minocycline between the saline- and LPS-pretreated mice was observed. However, we observed that the use of minocycline is problematic in studies of alcohol consumption, given its property to reduce water intake also, consistent with previous findings (Henry et al., 2008) and a very recent report testing several tetracyclines for further development of pharmacological treatments of alcohol-use disorder (Syapin et al., 2016).

Brilliant Blue $G$ is an antagonist of the ATP-dependent P2X7 receptors, which are linked to inflammatory responses in the central nervous system and also many neurologic and psychiatric disorders (Sperlágh \& Illes, 2014). We show here that subchronic treatment with Brilliant Blue $G$ has no effect on alcohol intake in the DID model, suggesting that the P2X7 receptors are not important in the regulation of binge-type alcohol consumption. Similar dosing of Brilliant Blue $G$ that we used has displayed central effects 
A DID1-5: $20 \%$ EtOH (2 h or 4 h)

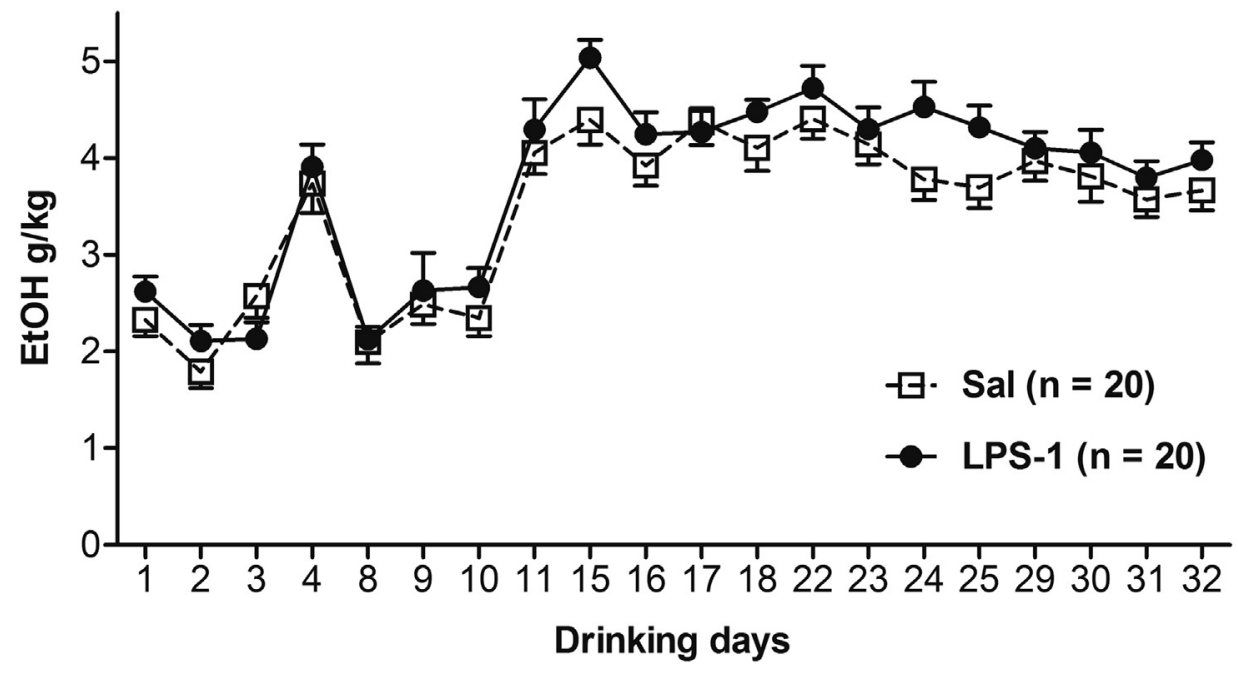

B DID5-11: 20\% EtOH, 4-day mean (4 h)

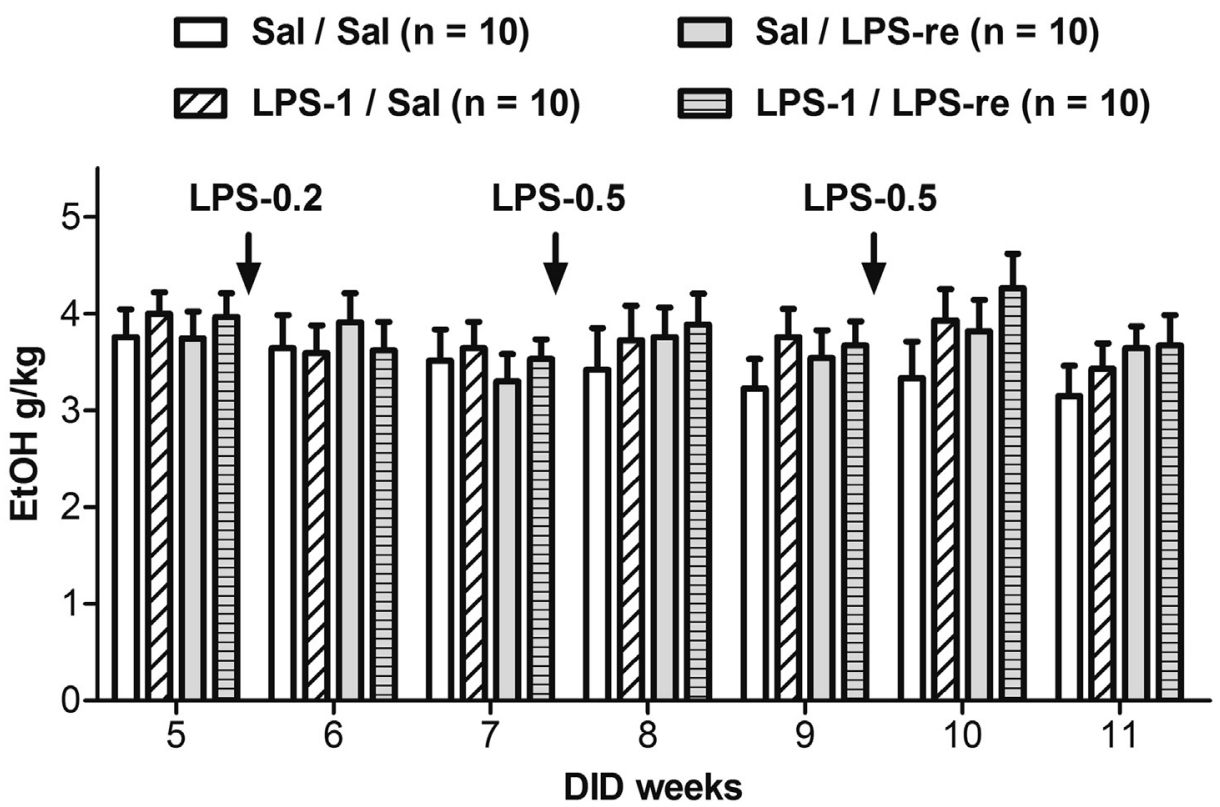

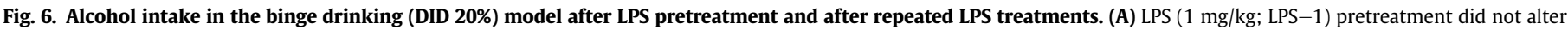

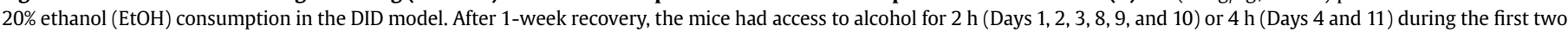

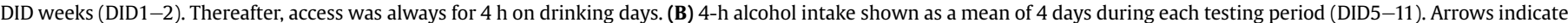

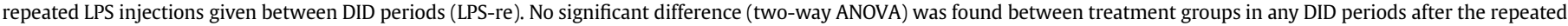
LPS injections. Sal, saline.

in producing antidepressant-like effects and attenuation of amphetamine-induced hyperactivity in mice (Csölle et al., 2013) and in prolonging latency to seizures (Fischer et al., 2016). Thus, at least a partial blockade of the P2X7 receptors is expected. However, further studies utilizing other centrally active antagonists are needed to clarify whether $\mathrm{P} 2 \mathrm{X} 7$ receptors play a role in regulation of alcohol drinking.

In conclusion, the LPS-induced sickness reaction does not consistently produce changes in brain functions that would enhance alcohol intake. Thus, our findings indicate that this LPS model is sensitive to factors difficult to control. Therefore, further studies are needed to develop this model, so it could become useful in studies of mechanisms underlying interactions between alcohol consumption and inflammation. Altogether, there is a clear need for animal models to analyze the role of neuroinflammation in alcohol abuse.

\section{Acknowledgments}

The study was supported by the Finnish Foundation for Alcohol Studies and Yrjö Jahnsson Foundation. We have no conflicts of interest to declare. The funders had no role in study design, data collection and analysis, preparation of the manuscript, or decision to publish. 


\section{Appendix A. Supplementary data}

Supplementary data related to this article can be found at http://dx.doi.org/10.1016/j.alcohol.2017.06.002.

\section{References}

Agrawal, R. G., Hewetson, A., George, C. M., Syapin, P. J., \& Bergeson, S. E. (2011). Minocycline reduces ethanol drinking. Brain Behavior and Immunity, 25(Suppl 1), S165-S169. http://dx.doi.org/10.1016/j.bbi.2011.03.002.

Agrawal, R. G., Owen, J. A., Levin, P. S., Hewetson, A., Berman, A. E., Franklin, S. R., et al. (2014). Bioinformatics analyses reveal age-specific neuroimmune modulation as a target for treatment of high ethanol drinking. Alcoholism Clinical and Experimental Research, 38, 428-437. http://dx.doi.org/10.1111/acer.12288.

Bahi, A. (2017). Environmental enrichment reduces chronic psychosocial stressinduced anxiety and ethanol-related behaviors in mice. Progress in Neuropsychopharmacology and Biological Psychiatry, 77, 65-74. http://dx.doi.org/ 10.1016/j.pnpbp.2017.04.001.

Banasikowski, T. J., Cloutier, C. J., Ossenkopp, K. P., \& Kavaliers, M. (2015). Repeated exposure of male mice to low doses of lipopolysaccharide: Dose and time dependent development of behavioral sensitization and tolerance in an automated light-dark anxiety test. Behavioural Brain Research, 286, 241-248. http:// dx.doi.org/10.1016/j.bbr.2015.03.004.

Beura, L. K., Hamilton, S. E., Bi, K., Schenkel, J. M., Odumade, O. A., Casey, K. A., et al. (2016). Normalizing the environment recapitulates adult human immune traits in laboratory mice. Nature, 532, 512-516. http://dx.doi.org/10.1038/nature17655.

Blednov, Y. A., Benavidez, J. M., Geil, C., Perra, S., Morikawa, H., \& Harris, R. A. (2011). Activation of inflammatory signaling by lipopolysaccharide produces a prolonged increase of voluntary alcohol intake in mice. Brain Behaviour and Immunity, 25(Suppl 1), S92-S105. http://dx.doi.org/10.1016/j.bbi.2011.01.008.

Blednov, Y. A., Ponomarev, I., Geil, C., Bergeson, S., Koob, G. F., \& Harris, R. A. (2012). Neuroimmune regulation of alcohol consumption: Behavioral validation of genes obtained from genomic studies. Addiction Biology, 17, 108-120. http:// dx.doi.org/10.1111/j.1369-1600.2010.00284.x.

Cox, B. R., Olney, J. J., Lowery-Gionta, E. G., Sprow, G. M., Rinker, J. A., Navarro, M., et al. (2013). Repeated cycles of binge-like ethanol (EtOH)-drinking in male C57BL/6J mice augments subsequent voluntary EtOH intake but not other dependence-like phenotypes. Alcoholism: Clinical and Experimental Research, 37, 1688-1695. http://dx.doi.org/10.1111/acer.12145.

Crabbe, J. C., Phillips, T. J., \& Belknap, J. K. (2010). The complexity of alcohol drinking: Studies in rodent genetic models. Behavior Genetics, 40, 737-750. http:// dx.doi.org/10.1007/s10519-010-9371-z.

Crews, F. T., Sarkar, D. K., Qin, L., Zou, J., Boyadjieva, N., \& Vetreno, R. P. (2015). Neuroimmune function and the consequences of alcohol exposure. Alcohol Research Current Reviews, 37(331-341), 344-351.

Crews, F. T., Zou, J., \& Qin, L. (2011). Induction of innate immune genes in brain create the neurobiology of addiction. Brain Behavior and Immunity, 25(Suppl 1), S4-S12. http://dx.doi.org/10.1016/j.bbi.2011.03.003.

Csölle, C., Andó, R. D., Kittel, Á., Gölöncsér, F., Baranyi, M., Soproni, K., et al. (2013). The absence of P2X7 receptors (P2rx7) on non-haematopoietic cells leads to selective alteration in mood-related behaviour with dysregulated gene expression and stress reactivity in mice. The International Journal of Neuropsychopharmacology, 16, 213-233. http://dx.doi.org/10.1017/S1461145711001933.

Dantzer, R., O'Connor, J. C., Freund, G. G., Johnson, R. W., \& Kelley, K. W. (2008). From inflammation to sickness and depression: When the immune system subjugates the brain. Nature Reviews Neuroscience, 9, 46-56. http://dx.doi.org/ $10.1038 / \mathrm{nrn} 2297$.

Edenberg, H. J., Xuei, X., Wetherill, L. F., Bierut, L., Bucholz, K., Dick, D. M., et al. (2008). Association of NFKB1, which encodes a subunit of the transcription factor NF-kappaB, with alcohol dependence. Human Molecular Genetics, 17, 963-970. http://dx.doi.org/10.1093/hmg/ddm368.

Engeland, C. G., Nielsen, D. V., Kavaliers, M., \& Ossenkopp, K. P. (2001). Locomotor activity changes following lipopolysaccharide treatment in mice: A multivariate assessment of behavioral tolerance. Physiology and Behavior, 72, 481-491.

Fischer, W., Franke, H., Krügel, U., Müller, H., Dinkel, K., Lord, B., et al. (2016). Critical evaluation of P2X7 receptor antagonists in selected seizure models. PLoS One, 11, e0156468. http://dx.doi.org/10.1371/journal.pone.0156468.

Harris, R. A., Bajo, M., Bell, R. L., Blednov, Y. A., Varodayan, F. P., Truitt, J., et al. (2016). Genetic and pharmacologic manipulation of TLR4 has minimal impact on ethanol consumption in rodents. The Journal of Neuroscience, 37, 1139-1155. http://dx.doi.org/10.1523/JNEUROSCI.2002-16.2016.

Harris, R. A., \& Blednov, Y. A. (2013). Neuroimmune genes and alcohol drinking behavior. In C. Cui, L. Grandison, \& A. Noronha (Eds.), Neural-immune interactions in brain function and alcohol related disorders (pp. 425-440). New York: Springer.

Henry, C. J., Huang, Y., Wynne, A., Hanke, M., Himler, J., Bailey, M. T., et al. (2008). Minocycline attenuates lipopolysaccharide (LPS)-induced neuroinflammation, sickness behavior, and anhedonia. Journal of Neuroinflammation, 5, 15. http:// dx.doi.org/10.1186/1742-2094-5-15.

Hoogland, I. C., Houbolt, C., van Westerloo, D. J., van Gool, W. A., \& van de Beek, D. (2015). Systemic inflammation and microglial activation: Systematic review of animal experiments. Journal of Neuroinflammation, 12, 114. http://dx.doi.org/ 10.1186/s12974-015-0332-6.
Hutchinson, M. R., \& Watkins, L. R. (2014). Why is neuroimmunopharmacology crucial for the future of addiction research? Neuropharmacology, 76(Pt B) 218-227. http://dx.doi.org/10.1016/j.neuropharm.2013.05.039.

Hwa, L. S., Kalinichev, M., Haddouk, H., Poli, S., \& Miczek, K. A. (2014). Reduction of excessive alcohol drinking by a novel GABAB receptor positive allosteric modulator ADX71441 in mice. Psychopharmacology (Berlin), 231, 333-343. http://dx.doi.org/10.1007/s00213-013-3245-z.

June, H. L., Liu, J., Warnock, K. T., Bell, K. A., Balan, I., Bollino, D., et al. (2015). CRFamplified neuronal TLR4/MCP-1 signaling regulates alcohol self-administration. Neuropsychopharmacology, 40, 1549-1559. http://dx.doi.org/10.1038/npp.2015.4.

Leclercq, S., Cani, P. D., Neyrinck, A. M., Stärkel, P., Jamar, F., Mikolajczak, M., et al (2012). Role of intestinal permeability and inflammation in the biological and behavioral control of alcohol-dependent subjects. Brain Behavior and Immunity, 26, 911-918. http://dx.doi.org/10.1016/j.bbi.2012.04.001.

Leclercq, S., Matamoros, S., Cani, P. D., Neyrinck, A. M., Jamar, F., Starkel, P., et al. (2014). Intestinal permeability, gut-bacterial dysbiosis, and behavioral markers of alcohol-dependence severity. Proceedings of the National Academy of Sciences of the United States of American, 111, E4485-E4493. http://dx.doi.org/10.1073/ pnas.1415174111.

Mantere, O., Soronen, P., Uher, R., Ketokivi, M., Jylhä, P., Melartin, T., et al. (2012) Neuroticism mediates the effect of P2RX7 on outcomes of mood disorders. Depression and Anxiety, 29, 816-823. http://dx.doi.org/10.1002/da.21945.

Marcos, M., Pastor, I., González-Sarmiento, R., \& Laso, F. J. (2008). Interleukin-10 gene polymorphism is associated with alcoholism but not with alcoholic liver disease. Alcohol and Alcoholism, 43, 523-528. http://dx.doi.org/10.1093/alcalc/agn026.

Marianno, P., Abrahao, K. P., \& Camarini, R. (2017). Environmental enrichment blunts ethanol consumption after restraint stress in C57BL/6 mice. PLoS One, 12 e0170317. http://dx.doi.org/10.1371/journal.pone.0170317.

Marshall, S. A., Casachahua, J. D., Rinker, J. A., Blose, A. K., Lysle, D. T., \& Thiele, T. E. (2016). IL-1 receptor signaling in the basolateral amygdala modulates binge-like ethanol consumption in male C57BL/6J mice. Brain Behavior and Immunity, 51, 258-267. http://dx.doi.org/10.1016/j.bbi.2015.09.006.

Marshall, S. A., Rinker, J. A., Harrison, L. K., Fletcher, C. A., Herfel, T. M., \& Thiele, T. E. (2015). Assessment of the effects of 6 standard rodent diets on binge-like and voluntary ethanol consumption in male C57BL/6J mice. Alcoholism Clinical and Experimental Research, 39, 1406-1416. http://dx.doi.org/10.1111/acer.12773.

McIver, S. R., Muccigrosso, M. M., \& Haydon, P. G. (2012). The effect of doxycycline on alcohol consumption and sensitivity: Consideration for inducible transgenic mouse models. Experimental Biology and Medicine, 237, 1129-1133. http:// dx.doi.org/10.1258/ebm.2012.012029.

Möller, T., Bard, F., Bhattacharya, A., Biber, K., Campbell, B., Dale, E., et al. (2016) Critical data-based re-evaluation of minocycline as a putative specific microglia inhibitor. Glia, 64, 1788-1794. http://dx.doi.org/10.1002/glia.23007.

Nuutinen, S., Lintunen, M., Vanhanen, J., Ojala, T., Rozov, S., \& Panula, P. (2011) Evidence for the role of histamine $\mathrm{H} 3$ receptor in alcohol consumption and alcohol reward in mice. Neuropsychopharmacology, 36, 2030-2040. http:// dx.doi.org/10.1038/npp.2011.90.

Pastor, I. J., Laso, F. J., Romero, A., \& González-Sarmiento, R. (2005). Interleukin-1 gene cluster polymorphisms and alcoholism in Spanish men. Alcohol and Alcoholism, 40, 181-186. http://dx.doi.org/10.1093/alcalc/agh153.

Qin, L., He, J., Hanes, R. N., Pluzarev, O., Hong, J. S., \& Crews, F. T. (2008). Increased systemic and brain cytokine production and neuroinflammation by endotoxin following ethanol treatment. Journal of Neuroinflammation, 5(10). http:// dx.doi.org/10.1186/1742-2094-5-10.

Ray, L. A., Roche, D. J., Heinzerling, K., \& Shoptaw, S. (2014). Opportunities for the development of neuroimmune therapies in addiction. International Review of Neurobiology, 118, 381-401. http://dx.doi.org/10.1016/B978-0-12-8012840.00012-9.

Rhodes, J. S., Best, K., Belknap, J. K., Finn, D. A., \& Crabbe, J. C. (2005). Evaluation of a simple model of ethanol drinking to intoxication in C57BL/6J mice. Physiology and Behavior, 84, 53-63. http://dx.doi.org/10.1016/j.physbeh.2004.10.007.

Soronen, P., Mantere, O., Melartin, T., Suominen, K., Vuorilehto, M., Rytsälä, H., et al. (2011). P2RX7 gene is associated consistently with mood disorders and predicts clinical outcome in three clinical cohorts. American Journal of Medical Genetics Part B Neuropsychiatric Genetics, 156B, 435-447. http://dx.doi.org/10.1002/ajmg.b.31179.

Sperlágh, B., \& Illes, P. (2014). P2X7 receptor: An emerging target in central nervous system diseases. Trends in Pharmacological Sciences, 35, 537-547. http:// dx.doi.org/10.1016/j.tips.2014.08.002.

Syapin, P. J., Martinez, J. M., Curtis, D. C., Marquardt, P. C., Allison, C. L., Groot, J. A et al. (2016). Effective reduction in high ethanol drinking by semisynthetic tetracycline derivatives. Alcoholism: Clinical and Experimental Research, 40 2482-2490. http://dx.doi.org/10.1111/acer.13253.

Taylor, A. M., Castonguay, A., Taylor, A. J., Murphy, N. P., Ghogha, A., Cook, C., et al (2015). Microglia disrupt mesolimbic reward circuitry in chronic pain. The Journal of Neuroscience, 35, 8442-8450. http://dx.doi.org/10.1523/JNEUROSCI.4036-14.2015.

Wahlsten, D., Bachmanov, A., Finn, D. A., \& Crabbe, J. C. (2006). Stability of inbred mouse strain differences in behavior and brain size between laboratories and across decades. Proceedings of the National Academy of Sciences of the United States of America, 103, 16364-16369. http://dx.doi.org/10.1073/pnas. 0605342103.

Wolstenholme, J. T., Warner, J. A., Capparuccini, M. I., Archer, K. J., Shelton, K. L., \& Miles, M. F. (2011). Genomic analysis of individual differences in ethano drinking: Evidence for non-genetic factors in C57BL/6 mice. PLoS One, 6, e21100. http://dx.doi.org/10.1371/journal.pone.0021100. 